\title{
Review
}

\section{The Treatment of Pulmonary Diseases and Respiratory-Related Conditions with Inhaled (Nebulized or Aerosolized) Glutathione}

\author{
Jonathan Prousky ${ }^{1,2}$ \\ ${ }^{1}$ The Canadian College of Naturopathic Medicine, 1255 Sheppard Avenue East, Toronto, ON M2K 1E2, Canada \\ and ${ }^{2}$ International Primary Health Care, The External Program, University of London, London, UK
}

\begin{abstract}
Reduced glutathione or simply glutathione ( $\gamma$-glutamylcysteinylglycine; GSH) is found in the cytosol of most cells of the body. GSH in the epithelial lining fluid (ELF) of the lower respiratory tract is thought to be the first line of defense against oxidative stress. Inhalation (nebulized or aerosolized) is the only known method that increases GSH's levels in the ELF. A review of the literature was conducted to examine the clinical effectiveness of inhaled GSH as a treatment for various pulmonary diseases and respiratory-related conditions. This report also discusses clinical and theoretical indications for GSH inhalation, potential concerns with this treatment, its presumed mechanisms of action, optimal doses to be administered and other important details. Reasons for inhaled GSH's effectiveness include its role as a potent antioxidant, and possibly improved oxygenation and host defenses. Theoretical uses of this treatment include Farmer's lung, pre- and postexercise, multiple chemical sensitivity disorder and cigarette smoking. GSH inhalation should not be used as a treatment for primary lung cancer. Testing for sulfites in the urine is recommended prior to GSH inhalation. Minor side effects such as transient coughing and an unpleasant odor are common with this treatment. Major side effects such as bronchoconstriction have only occurred among asthma patients presumed to be sulfite-sensitive. The potential applications of inhaled GSH are numerous when one considers just how many pulmonary diseases and respiratory-related conditions are affected by deficient antioxidant status or an over production of oxidants, poor oxygenation and/or impaired host defenses. More studies are clearly warranted.
\end{abstract}

Keywords: aerosolized glutathione $(\mathrm{GSH})$ - antioxidant - inhaled GSH - nebulized GSH reduced GSH

\section{Introduction}

Reduced glutathione or simply glutathione ( $\gamma$-glutamylcysteinylglycine; GSH) is found in the cytosol of most cells of the body (1). It is a tripeptide consisting of glycine, cysteine and glutamate. GSH functions in several enzyme systems within the body that assist with the quenching of free radicals and the detoxification of fat-soluble compounds (Table 1) (2-5). It also plays a significant metabolic role in supporting many different

For reprints and all correspondence: Jonathan Prousky, 1255 Sheppard Avenue East, Toronto, Ontario, Canada MK2 1E2. Tel: 416-498-1255, ext. 235; Fax: 416-498-1611; E-mail: jprousky@ccnm.edu biochemical processes (e.g. amino acid transport, deoxyribonucleic acid synthesis and immune system augmentation) considered to be important mediators of health status (6).

Glutathione in the epithelial lining fluid (ELF) of the lower respiratory tract is thought to be the first line of defense against oxidative stress (6). The ELF concentration of GSH is 140 times that of serum concentrations with a redox ratio of $>9: 1$ (7). In fact, alternations in alveolar and lung GSH metabolism are widely recognized as a central feature among many inflammatory lung diseases (8-14). In healthy lungs, the oxidant burden is balanced by local antioxidant defenses. However, in lung 
Table 1. Enzyme systems involving glutathione

\begin{tabular}{ll}
\hline Enzyme system & Function \\
\hline $\begin{array}{l}\text { Glutathione synthetase } \\
\text { Riboflavin-containing glutathione reductase }\end{array}$ & $\begin{array}{l}\text { Gamma-glutamyl cycle. } \\
\text { Catalyzes the conversion of oxidized glutathione } \\
\text { (glutathione disulfide; GSSG) to its reduced form. } \\
\text { Conjugation of GSH with fat-soluble substances for } \\
\text { liver detoxification and the detoxification of } \\
\text { environmental carcinogens, such as those found in tobacco smoke. }\end{array}$ \\
$\begin{array}{l}\text { Pelenium-containing glutathione } \\
\text { peroxidase (GPX) }\end{array}$ & $\begin{array}{c}\text { If not neutralized, these peroxides will damage cellular membranes } \\
\text { and other vital cellular components. }\end{array}$ \\
$\begin{array}{l}\text { Leukotriene } \mathrm{C}_{4} \text { synthase } \\
\text { Conjugation of leukotriene } \mathrm{A}_{4} \text { with GSH, resulting in the generation } \\
\text { of leukotrienes } \mathrm{C}_{4} \text {. Gamma-glutamyl transpeptidase then metabolizes } \\
\text { leukotrienes } \mathrm{C}_{4} \text { to leukotrienes } \mathrm{D}_{4} .\end{array}$ \\
\hline
\end{tabular}

diseases cellular damage and injury is mediated by an increased oxidant burden and/or decreased antioxidant defenses.

In inflammatory lung diseases, supplementation with exogenous sources of GSH would be necessary to reduce the oxidant load and/or correct for antioxidant deficiencies within the lungs. A few published clinical studies have shown the oral administration of GSH to be ineffective at increasing plasma levels when given to healthy subjects (15), or when used for the treatment of hepatic cirrhosis (16). If the oral administration of GSH cannot raise plasma levels in healthy and diseased patients, it is doubtful that this method of delivery would have any appreciable effects at increasing GSH concentrations within the lungs.

Intravenous administration might be effective since it bypasses the gastrointestinal tract, immediately enters the blood stream, and presumably would saturate body tissues such as the lungs. Unfortunately, the results of a study did not show intravenous administration to be effective at increasing GSH levels within the ELF (17). When $600 \mathrm{mg}$ of GSH was delivered intravenously to sheep, the levels in the venous plasma, lung lymph and ELF increased only for a very brief period of time. However, when the same amount of GSH was delivered through inhalation (nebulized or aerosolized), the baseline GSH level in the ELF $(45.7 \pm 10 \mu \mathrm{M})$ increased 7 -fold at 30 -min $(337 \pm 64 \mu \mathrm{M})$, remained above the baseline level $1 \mathrm{~h}$ later $(P<0.001)$ and returned toward baseline levels by $2 \mathrm{~h}$. Despite this short-term increase in GSH concentrations within the ELF, the inhalation method did not significantly increase the amount of GSH in the lung lymph, venous plasma and urine during the $2 \mathrm{~h}$ study period. The authors of this report concluded that inhalation specifically increased GSH levels at the lung epithelial surface.

Given that inhalation is the only known method that increases GSH levels in the ELF for a significant duration, a review of the literature was conducted to examine the clinical effectiveness of inhaled GSH as a treatment for various pulmonary diseases and respiratory-related conditions. Only reports involving human subjects were included in the analysis. The clinical and theoretical indications for GSH inhalation were summarized and potential concerns with this treatment reported. Other pertinent details such as its presumed mechanisms of action and optimal doses to be administered were compiled and evaluated.

\section{Methods}

\section{Literature Search}

Computer searches were conducted of English and nonEnglish language articles in the Biomedical Reference Collection (1984 to August 2006), CINAHL (1982 to August 2006), MEDLINE (1965 to August 2006) and Nursing and Allied Health Collection (1985 to August 2006) databases. Articles were searched with the key search terms 'Nebulized Glutathione,' and 'Glutathione' in combination with 'Aerosol' OR 'Inhalation.' These keywords were also searched with words related to pulmonary and/or respiratory disease. To supplement the search, references of the articles found from the initial search were reviewed. Hand searching of relevant journals was also completed as part of the search.

\section{Selection of Articles}

To be included in the final review, articles had to report on the use and administration of inhaled GSH for pulmonary diseases and respiratory-related conditions in human subjects. Only peer-reviewed articles were reviewed.

\section{Quality Assessment}

An evidence grade was determined for each article. These evidence grades were adapted from the hierarchy of evidence developed by the Oxford Centre of Evidence Based Medicine (Table 2) (18). 
Table 2. Grades of evidence

\begin{tabular}{|c|c|}
\hline $\mathrm{A}$ & $\begin{array}{l}\text { Systematic reviews of randomized controlled trials } \\
\text { and/or randomized controlled trials with or without } \\
\text { double-blind placebo control. }\end{array}$ \\
\hline B & $\begin{array}{l}\text { Systematic reviews of observational studies and/or } \\
\text { high-quality observational studies including } \\
\text { cohort and case-control studies and/or cohort } \\
\text { 'outcomes' research and/or nonrandomized } \\
\text { controlled trials. }\end{array}$ \\
\hline C & $\begin{array}{l}\text { Case-series, case-reports, and/or poor-quality } \\
\text { cohort and case-control studies. }\end{array}$ \\
\hline $\mathrm{D}$ & $\begin{array}{l}\text { Expert opinion without explicit critical appraisal } \\
\text { or based on physiology, bench research or } \\
\text { 'first principles.' }\end{array}$ \\
\hline
\end{tabular}

\section{Results}

A total of 12 reports were screened $(9,10,17,19-27)$. Only one report was excluded because it involved the use of inhaled GSH in sheep (17). In total, 11 articles were found to meet the inclusion criteria and were included in this review $(9,10,19-27)$. Table 3 displays the characteristics of the studies included in this review.

\section{Discussion}

Based exclusively on the published evidence included in this review, inhaled GSH is potentially indicated for the following clinical conditions: cystic fibrosis (CF), chronic otitis media with effusion (OME), HIV seropositive individuals, idiopathic pulmonary fibrosis (IPF) and chronic rhinitis. These conditions were chosen since the published studies were of good quality, received A and B evidence grades, and their respective results demonstrated benefits from the use of GSH inhalation.

Inhaled GSH cannot be recommended as a potential treatment for emphysema since the quality of evidence is lacking at the present time. The emphysema case report had notable limitations since serial spirometry was not documented, and the placebo effect could not be ruled-out (22). However, this does not necessarily indicate that GSH inhalation would be of no benefit for emphysema patients. There is experimental and human data demonstrating a link between GSH, oxidantderived damage and possible protection against the development of emphysema. An in vitro study demonstrated that GSH could retard the oxidant-mediated down-regulation of $\alpha$-1-proteinase inhibitor activity in smokers' emphysema (28). This finding is important since one of the principal pathophysiological mechanisms of emphysema is the down-regulation of this enzyme by means of oxidative damage (29). Moreover, in a recent review of lung GSH and cigarette smoke-induced airway disease, increased GSH in the ELF of chronic smokers was presumed to be a protective adaptive mechanism against the development of chronic obstructive pulmonary disease (COPD) (30). Considering that not all chronic smokers go on to develop COPD, the authors in that review pointed out that genetic variations in the molecular mechanisms that regulate GSH metabolism might explain why some individuals are better protected against the development of COPD. It thus appears that emphysema patients are subjected to progressive tissue damage due, in part, to the consequences of GSH deficiency and/or genetic variations in GSH metabolism. Since GSH inhalation would presumably offer both antioxidant protection and GSH replenishment, this method of treatment would potentially benefit emphysema patients.

Asthma is another condition where inhaled GSH cannot be recommended since this treatment caused notable side effects (e.g. breathlessness, bronchoconstriction and cough) in the cited study (21). These side effects were linked primarily to the production of sulfites that occurred when GSH was in solution. GSH inhalation should continue to be explored as a potential treatment for asthma. None of the asthma patients in the study had their urine tested for sulfites. A positive test for sulfites would have eliminated these patients from entering the study. Accordingly, the results might have been much more favorable if patients without sulfite sensitivities were included.

This issue of asthma and sulfite sensitivities is an important one for clinicians to be mindful of. Sulfites are found in beer, wine, restaurant salad bars, seafood, potatoes, processed foods and many pharmaceuticals (31). Many asthma patients report being sensitive to sulfites. In an Australian study, $\sim 30 \%$ of asthmatic patients reported being sensitive to sulfites in wine (32). A more recent and rigorous scientific study, however, demonstrated that asthma patients can tolerate varying amounts of sulfites in wines ranging from 20,75 or 150 parts per million ( $\mathrm{ppm}$ ) (33). Only a small minority of patients in this study (4 of 24 self-reported wine-sensitive asthmatics) exhibited reactions when challenged with $300 \mathrm{ppm}$ of sulfites. One report indicated that $4-8 \%$ of asthmatics are sensitive to sulfites (34). Other reports have estimated the incidence of sulfite sensitivity to be around $5-11 \%(35,36)$. Even though the exact percentage of sulfite-sensitive asthmatics is difficult to ascertain, sulfite sensitivity is an important factor to assess when using or evaluating research done on inhaled GSH.

\section{Future Research Directions}

There are additional clinical conditions that might benefit from this type of treatment, but further studies are necessary. One such condition is Farmer's lung (FL), which is a hypersensitivity pneumonitis caused by the inhalation of thermophilic actinomycetes and spores of Aspergillus specie (11). A study was undertaken to investigate the effect of pulmonary GSH levels after hay exposure in patients with FL and in asymptomatic farmers (AF) (11). Fifteen symptomatic patients with FL 
Table 3. Summary of articles demonstrating the effectiveness of inhaled glutathione for the treatment of pulmonary diseases and respiratory-related conditions

\begin{tabular}{|c|c|c|c|c|c|}
\hline Reference & Condition & $N$ & $\begin{array}{l}\text { Dosages of inhaled } \\
\text { GSH }\end{array}$ & Outcome & Evidence grade \\
\hline (24) & Cystic fibrosis (CF) & $\begin{array}{l}\text { Nine patients [mean age, } \\
16.1 \pm 1.44(\mathrm{SD}) \text { years] } \\
\text { received the } \\
\text { S-nitrosoglutathione } \\
\text { (GSNO) and } \\
11 \text { patients [mean age, } \\
19.9 \pm 3.45 \text { (SD) years] } \\
\text { received the phosphate- } \\
\text { buffered saline (PBS) } \\
\text { solution }\end{array}$ & $\begin{array}{l}0.05 \mathrm{ml} / \mathrm{kg} \text { of } 10 \mathrm{mM} \\
\text { GSNO }\end{array}$ & $\begin{array}{l}\text { The treatment group } \\
\text { showed a modest } \\
\text { improvement in } \\
\text { oxygenation that was } \\
\text { thought to be } \\
\text { independent of the } \\
\text { physiological effects of } \\
\text { nitric oxide. }\end{array}$ & $\begin{array}{l}\text { A: Randomized } \\
\text { placebo-controlled trial }\end{array}$ \\
\hline (27) & $\mathrm{CF}$ & $\begin{array}{l}19 \text { patients }(6-19 \text { years of } \\
\text { age) were randomized to } \\
\text { treatment [mean age, } \\
13.3 \pm 4.1 \text { (SD) years] or } \\
\text { placebo groups [mean age, } \\
12.9 \pm 4.9 \text { (SD) years] }\end{array}$ & $\begin{array}{l}\text { Total daily dose } \\
\text { administered to the } \\
\text { patients in the } \\
\text { treatment group was } \\
66 \mathrm{mg} / \mathrm{kg} \text { of body } \\
\text { weight }\end{array}$ & $\begin{array}{l}\text { GSH can improve } \\
\text { clinical parameters in } \\
\text { CF patients, and that } \\
\text { effective treatment } \\
\text { should include the } \\
\text { correction of GSH } \\
\text { deficiency. }\end{array}$ & $\begin{array}{l}\text { A: Randomized } \\
\text { placebo-controlled trial }\end{array}$ \\
\hline (9) & $\begin{array}{l}\text { Idiopathic } \\
\text { pulmonary } \\
\text { fibrosis (IPF) }\end{array}$ & $\begin{array}{l}10 \text { patients with IPF [mean } \\
\text { age, } 46 \pm 3(\mathrm{SD}) \text { years] and } \\
19 \text { normal nonsmokers } \\
\text { [mean age, } 36 \pm 3 \\
\text { (SD) years] }\end{array}$ & $\begin{array}{l}600 \mathrm{mg} \text { twice daily for } \\
3 \text { days }\end{array}$ & $\begin{array}{l}\text { Inhaled GSH might be } \\
\text { beneficial among IPF } \\
\text { patients by reversing the } \\
\text { oxidant-antioxidant } \\
\text { imbalance. }\end{array}$ & $\begin{array}{l}\text { B: Nonrandomized con- } \\
\text { trolled trial }\end{array}$ \\
\hline$(20)$ & Chronic rhinitis & $\begin{array}{l}13 \text { patients with chronic } \\
\text { rhinitis and } 13 \text { healthy } \\
\text { subjects ( } 4-15 \text { years of age } \\
\text { for all subjects; mean age, } \\
8.2 \text { years) }\end{array}$ & $600 \mathrm{mg}$ daily for 14 days & $\begin{array}{l}\text { Statistically significant } \\
\text { improvement in nasal } \\
\text { obstruction, rhinorrhea } \\
\text { and ear fullness. }\end{array}$ & $\begin{array}{l}\text { B: Nonrandomized } \\
\text { controlled trial }\end{array}$ \\
\hline (10) & $\mathrm{CF}$ & $\begin{array}{l}\text { Seven CF patients [mean } \\
\text { age, } 25 \pm 1 \text { (SD) years] }\end{array}$ & $\begin{array}{l}600 \mathrm{mg} \text { of } \mathrm{GSH} \text { for } \\
3 \text { days }\end{array}$ & $\begin{array}{l}\text { Inhalation therapy with } \\
\text { GSH does normalize } \\
\text { the respiratory } \\
\text { epithelial surface } \\
\text { oxidant-antioxidant } \\
\text { balance in CF patients. }\end{array}$ & $\begin{array}{l}\text { B: Cohort 'outcomes' } \\
\text { research }\end{array}$ \\
\hline$(25)$ & $\mathrm{CF}$ & $\begin{array}{l}21 \text { patients with CF (16-37 } \\
\text { years of age for all } \\
\text { subjects) }\end{array}$ & $\begin{array}{l}300 \text { or } 450 \mathrm{mg} \text { three } \\
\text { times daily for } 14 \text { days }\end{array}$ & $\begin{array}{l}\text { Inhaled GSH } \\
\text { can permeate the lower } \\
\text { airways of the lungs } \\
\text { and improve important } \\
\text { parameters of lung } \\
\text { function in CF patients } \\
\text { despite not having any } \\
\text { effect upon markers of } \\
\text { oxidative injury. }\end{array}$ & $\begin{array}{l}\text { B: Cohort 'outcomes' } \\
\text { research }\end{array}$ \\
\hline
\end{tabular}


Table 3. Continued

\begin{tabular}{|c|c|c|c|c|c|}
\hline Reference & Condition & $N$ & $\begin{array}{l}\text { Dosages of inhaled } \\
\text { GSH }\end{array}$ & Outcome & Evidence grade \\
\hline (26) & $\mathrm{CF}$ & $\begin{array}{l}17 \text { patients with CF (18-29 } \\
\text { years of age for all subjects; } \\
\text { mean age, } 24 \text { years) }\end{array}$ & $\begin{array}{l}450 \mathrm{mg} \text { three times daily } \\
\text { for } 14 \text { days }\end{array}$ & $\begin{array}{l}\text { Inhaled GSH did not } \\
\text { affect the oxidative } \\
\text { status of the patients } \\
\text { who were tested, but it } \\
\text { did favorably modulate } \\
\text { their immune responses. }\end{array}$ & $\begin{array}{l}\text { B: Cohort 'outcomes' } \\
\text { research }\end{array}$ \\
\hline
\end{tabular}

[mean age, $42 \pm 1(\mathrm{SD})$ year] were compared with $10 \mathrm{AF}$ [mean age, $43 \pm 1$ (SD) year] serving as the control group. All patients had baseline lung function testing and testing at various time intervals following hay exposures. The authors of this study concluded that FL and AF patients have characteristically different intrapulmonary levels of $\mathrm{GSH}$, and that the pathogenesis of FL is likely related to GSH regulatory mechanisms. They also speculated that AF patients have a better ability to upregulate their pulmonary GSH levels, which would protect them against active disease. Clinical testing of inhaled GSH in patients with FL is warranted.

The administration of GSH inhalation before and/or immediately following exercise is another potential application of this novel treatment. Exercise is a known inducer of oxidative stress leading to free radical production, which can encourage lipid peroxidation and tissue damage among individuals with deficient and/or impaired antioxidant systems. As stated in the beginning of this report, selenium is a cofactor in the GPX enzyme that protects cells from hydrogen peroxides and lipid hydroperoxides. When under situations of oxidative stress, the GPX enzyme will markedly increase in the lungs as an antioxidant adaptive response (37). By supplying more GSH to the lung tissues, more of this enzyme might be available to help reduce the production of free radicals associated with exercise. Although these assumptions are very speculative, it does seem possible and even logical that GSH inhalation would benefit those who regularly exercise by increasing exercise tolerance, and by maintaining and/or replenishing the antioxidant systems within the lungs.

Multiple chemical sensitivity disorder (MCSD) is another condition that might be clinically responsive to this treatment. Patients with this disorder are known to have bronchial hyperreactivity and even exhibit asthmalike symptoms (38). Unlike asthma, MCSD is not associated with atopy and immunoglobulin E (IgE)mediated allergic mechanisms (39). The prevailing theory explaining the cause of MCSD is a fusion between two separate theories - the neural sensitization and nitric oxide/peroxynitrite theories (40). This fusion theory, proposed by Pall, links long term potentiation of $N$ methyl-d-aspartate (NMDA) receptors at the synapses of nerve cells by glutamate and aspartate to an increased production of nitric oxide and its oxidant product, peroxynitrite $(40,41)$. Treatment with antioxidants may improve symptoms of MCSD by reducing the peroxynitrite elevations and other biochemical dysfunctions that are associated with such elevations $(40,41)$. Glutathione inhalation may be ideal since the primary route by which patients with MCSD get triggered is through smelling and breathing. Sulfite sensitivity would have to be considered since inhaled GSH could provoke adverse events. This treatment might be capable of providing antioxidant protection to both the upper and lower respiratory airways, which would theoretically help to reduce the symptoms of MCSD and the production of peroxynitrite. More research studies are necessary.

Two final conditions, cigarette smoking and lung cancer, are worth mentioning since they are intimately related to each other and are affected by GSH and its related enzymes. These conditions are influenced by the glutathione S-transferase (GST) group of enzymes that are found in significant quantities in the bronchioles and alveoli of the lungs (42), and in very high concentrations in the bronchial epithelium (43). Among smokers, a lack of the GST mu enzyme was thought to be associated with a greater risk of lung cancer, especially if there was a cancer and/or lung cancer history among the relatives of the patients in this study (44). Since the GST mu enzyme detoxify carcinogens in tobacco, any deficiency of this enzyme was presumed to be associated with an increased risk of lung cancer. However, a more recent study pertaining to the GST group of enzymes found no such association (45). In this meta-analysis, polymorphisms in the GST genes had no associations or weakly positive associations with risk factors for lung cancer. Despite the 
need for more research, GSH inhalation might be beneficial for smokers to augment their GST enzymes, which would help facilitate the detoxification of carcinogens. Even though the best intervention for these patients would be smoking cessation, many patients lack the necessary willpower to quit. For these patients, regular GSH inhalation might reduce oxidants generated from cigarette smoke $\left(\sim 10^{14}\right.$ free radicals/puff) (46), and the epithelial lung injury associated with smoking (47).

For lung cancer patients, the use of GSH inhalation is not recommended. Cancer cells use multiple mechanisms (e.g. altered transport of a drug, inhibition of druginduced apoptosis and elevation of cellular GSH) to circumvent the cytotoxic effects of chemotherapeutic agents (48). Early research studies showed that GSH was able to reduce cytotoxicity to chemotherapeutic compounds by boosting the metabolism of drugs to less active compounds, or by the detoxification of free radicals $(49,50)$. More recently, research has revealed that the levels of a specific GST enzyme increases among cancer cells with higher differentiation grades, and that these drug-resistant gene products are found in lung carcinomas at the time of surgical resection (51). There is also speculation that GSH might be capable of repairing drug-induced injury at the DNA level (48). A recent review article has described the involvement of glutathione in the detoxification or inactivation of platinum drugs - the most commonly employed drugs for the treatment of advanced stage lung cancer patients (52). Based on this information, it would be unwise and illogical to use GSH inhalation while lung cancer patients are undergoing active chemotherapy treatment.

\section{Mechanism of Action}

Inhalation of GSH results in a mechanism of action confined to the upper airways and lungs (Fig. 1), and will not influence plasma levels to a significant degree. In the studies that measured both lung and plasma levels of GSH, the plasma levels remained essentially unchanged following GSH inhalation. Seven of the studies included in this review demonstrated that GSH inhalation exerts its effects upon the lower respiratory tract $(9,10,19,24-27)$. The upper respiratory tract also appears to benefit from GSH augmentation. Two studies involving patients with upper respiratory tract diseases showed clinical benefits from GSH inhalation treatment $(20,23)$. The predominant mechanism responsible for GSH's therapeutic effects are probably related to its antioxidant properties that offer protection against oxidative injury, and/or assist with the normalization of the oxidantantioxidant balance within the upper and lower respiratory tract. Even though the majority of these studies suggested that antioxidant protection was the principal reason for the favorable treatment responses, some of the studies were unable to demonstrate a change in markers of oxidation from this treatment. More data is necessary to confirm the precise nature of GSH's antioxidant properties within the upper and lower respiratory tract. Additional explanations for GSH's therapeutic effects might include an improvement in host defenses (e.g. increased cytotoxic lymphocytes), and better oxygenation (e.g. an increase in oxygen saturation). GSH inhalation produced clinically meaningful results in the majority of diseases that were studied. Specifically, GSH inhalation was shown to improve clinical markers of respiratory function that inevitably impact upon quality of life and disease progression. These improvements were the most important outcomes and features of this novel treatment.

\section{Considerations Prior to Initiating GSH Inhalation}

The urine should be tested for sulfite sensitivity. A special test strip can be dipped in the urine, and is known as the 'EM-Quant 10013 Sulfite Test.' It can be easily located through any search engine on the Internet (53). Even though instructions for sulfite testing have been published elsewhere (54), a brief description of the procedure is outlined below:

A random (fresh) urine sample is suitable, but a first morning void may be preferable due to its higher concentration. Once the test strip is dipped in the urine (for $1 \mathrm{~s}$ ), the reaction zone changes color to indicate the concentration of sulfites present. After $30 \mathrm{~s}$, the color on the test strip is compared to a color scale on the bottle indicating the concentrations of sulfites in the urine (can detect 10, 40, 80, 180 and $400 \mathrm{ppm}$ of sulfites). The resultant concentration should be multiplied by a factor of 1.5 to provide the amount of free sulfites in $\mathrm{mg} / \mathrm{l}(\mathrm{ppm})$. The strip will not detect below $10 \mathrm{ppm}$. The urine samples should be preservative free, and the urinary $\mathrm{pH}$ should also be tested with $\mathrm{pH}$ paper. If the urine $\mathrm{pH}$ is below 6 , then the amount of sulfites might be underestimated by the test. In such cases, consider adding sodium acetate or sodium hydroxide to raise the $\mathrm{pH}$ to at least $7-10$ (should not exceed a $\mathrm{pH}$ of 12), and then repeat with a new test strip.

If the urine test were positive for sulfites (normally they are absent), the use of inhaled GSH would be strictly contraindicated.

\section{Method of Delivery, Recommended Daily Dosages and Side Effects}

With a nebulizer, a solution of GSH is made into an aerosol and is delivered to the upper respiratory tract and the lungs through a mask that covers the nose and mouth, or is delivered directly into the lungs via a mouthpiece. Any compounding pharmacist would be 


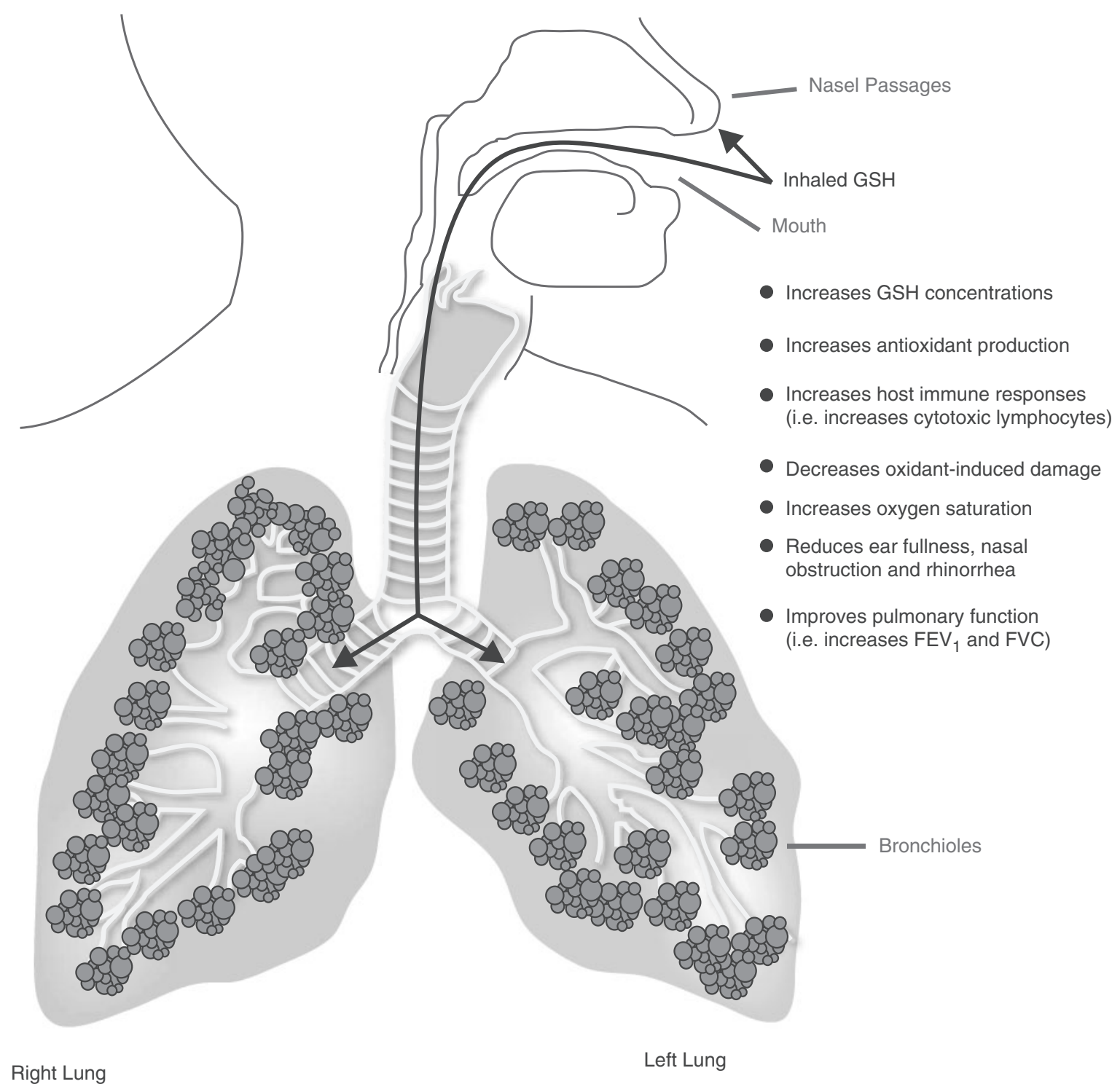

Figure 1. Inhaled GSH's mechanism of action. GSH, reduced glutathione; $\mathrm{FEV}_{1}$, forced expiratory volume in $1 \mathrm{~s}$; FVC, forced vital capacity.

able to prepare the solution of GSH at the desired concentrations. The typical dosages used in the studies cited in Table 3 were $600 \mathrm{mg}$ once daily, $600 \mathrm{mg}$ twice daily, $900 \mathrm{mg}$ daily, $1350 \mathrm{mg}$ daily or a daily dose of $66 \mathrm{mg} / \mathrm{kg}$ of body weight. Better results are more likely to be achieved with doses of at least $600 \mathrm{mg}$ or more each day. One of the studies used much larger doses $(66 \mathrm{mg} / \mathrm{kg}$ of body weight) since the authors speculated that these would be necessary to replace half of the amount of GSH that is produced each day (e.g. a $150 \mathrm{lb}$ male synthesizes $10 \mathrm{~g}$ daily and would need $5 \mathrm{~g}$ as a replacement dose) (27). When patients are unresponsive to doses in the range of 600-1350 mg per day, it might be suitable to try doses that would replace half the estimated amount of GSH that is synthesized each day. These gram doses might yield better clinical results.

In terms of side effects, GSH inhalation is very safe. Minor side effects such as mild coughing and an unpleasant odor were reported in some of the studies included in this review. These minor side effects, better described as mild nuisance problems, were not severe enough to cause any of the study participants to discontinue treatment with inhaled GSH. The only worrisome or potentially life-threatening side effect to note is bronchoconstriction, which would be more likely to occur among sulfite-sensitive asthma and MCSD patients. However, if proper precautions such as sulfite testing are done prior to treatment, this serious side effect should be avoidable.

\section{Monitoring the Clinical Response to Inhaled GSH}

For pulmonary diseases or respiratory-related conditions, baseline pulmonary function testing with a spirometer or a simple peak flow meter is recommended prior to the 
first treatment. After a prescribed period of treatment time, pulmonary function tests should be repeated. This will help to establish if there are any clinical improvements from regular GSH inhalation.

\section{Conclusions}

GSH inhalation is an effective treatment for a variety of pulmonary diseases and respiratory-related conditions. Even very serious and difficult-to-treat diseases (e.g., CF, IPF) yielded benefits from this novel treatment. GSH inhalation is very safe, and rarely causes major or lifethreatening side effects. The potential applications are numerous when one considers just how many pulmonary diseases and respiratory-related conditions are affected by deficient antioxidant status, poor oxygenation and/or impaired host defenses. More studies are clearly warranted.

\section{Acknowledgments}

The author would like to thank Mr Glen Carr and Mr Andrew Dick for their wonderful illustration of GSH's mechanism of action.

\section{References}

1. Groff JL, Gropper SS, Hunt SM. Advanced Nutrition and Human Metabolism, 2nd edn. St. Paul, MN: West Publishing Company, 1995, 165-6.

2. Bhagavan NV. Medical Biochemistry. Boston, MA: Jones and Bartlett, 1992, 323-4.

3. Kidd PM. Glutathione: systemic protectant against oxidative and free radical damage. Altern Med Rev 1997;2:155-76.

4. Tate SS, Meister A. Gamma-glutamyl transpeptidase: catalytic, structural and functional aspects. Mol Cell Biochem 1981;39:357-68.

5. Yoshimoto T, Soberman RJ, Spur B, Austen KV. Properties of highly purified leukotriene $\mathrm{C}_{4}$ synthase of guniea pig lung. $J$ Clin Invest 1988;81:866-71.

6. Lomaestro B, Malone M. Glutathione in health and disease: pharmacotherapeutic issues. Ann Pharmacother 1995;29:1263-73.

7. Cantin AM, North SL, Hubbard RC, Crystal RG. Normal alveolar epithelial lining fluid contains high levels of glutathione. $J$ Appl Physiol 1987;63:152-7.

8. Rahman I, MacNee W. Oxidative stress and regulation of glutathione in lung inflammation. Eur Respir $J$ 2000;16:534-54.

9. Borok Z, Buhl R, Grimes GJ, Bokser AD, Hubbard RC, Holroyd KJ, et al. Effect of glutathione on oxidant-antioxidant imbalance in idiopathic pulmonary fibrosis. Lancet 1991;338:215-6.

10. Roum JH, Borok Z, McElvaney NG, Grimes GJ, Bokser AD, Buhl R, et al. Glutathione aerosol suppresses lung epithelial surface inflammatory cell-derived oxidants in cystic fibrosis. J Appl Physiol 1999;87:438-43.

11. Behr J, Degenkolb B, Beinert T, Krombach F, Vogelmeier C. Pulmonary glutathione levels in acute episodes of Farmer's lung. Am J Respir Crit Care Med 2000;161:1968-71.

12. Buhl R, Vogelmeier C. Therapy for lung diseases with anti-oxidants. Pneumologie 1994;48:50-6.

13. Buhl R, Meyer A, Vogelmeier C. Oxidant-protease interaction in the lung. Prospects for antioxidant therapy. Chest 1996;110 (6 Suppl):267S-72S.

14. Gressier B, Lebegue S, Gosset P, Brunet C, Luyckx M, Dine T, et al. Protective role of glutathione on alpha 1 proteinase inhibitor inactivation by myeloperoxidase system. Hypothetic study for therapeutic strategy in the management of smoker's emphysema. Fundam Clin Pharmacol 1994;8:518-24.
15. Witschi A, Reddy S, Stofer B, Lauterburg BH. The systemic availability of oral glutathione. Eur J Clin Pharmacol 1992;43:667-9.

16. Cook GC, Sherlock S. Results of a controlled clinical trial of glutathione in cases of hepatic cirrhosis. Gut 1965;6:472-6.

17. Buhl R, Vogelmeier C, Critenden M, Hubbard RC, Hoyt RF Jr, Wilson EM, et al. Augmentation of glutathione in the fluid lining the epithelium of the lower respiratory tract by directly administering glutathione aerosol. Proc Natl Acad Sci USA 1990;87:4063-7.

18. Centre for Evidence-Based Medicine: <http://www.cebm.net/ levels_of_evidence.asp\#levels> 2006.

19. Holroyd KJ, Buhl R, Borok Z, Roum JH, Bokser AD, Grimes GJ, et al. Correction of glutathione deficiency in lower respiratory tract of HIV seropositive individuals by glutathione aerosol treatment. Thorax 1993;48:985-9.

20. Testa B, Mesolella M, Testa D, Giuliano A, Costa G, Maione F, et al. Glutathione in the upper respiratory tract. Ann Otol Rhinol Laryngol 1995;104:117-9.

21. Marrades RM, Roca J, Barberà JA, de Jover L, MacNee W, Rodriguez-Roisin R. Nebulized glutathione induces bronchoconstriction in patients with mild asthma. Am J Respir Crit Care Med 1997; 156:425-30.

22. Lamson DW, Brignall MS. The use of nebulized glutathione in the treatment of emphysema: a case report. Altern Med Rev 2000;5:429-31.

23. Testa B, Testa D, Mesolella M, D'Errico G, Tricarico D, Motta G. Management of chronic otitis media with effusion: the role of glutathione. Laryngoscope 2001;111:1486-9.

24. Snyder AH, McPherson ME, Hunt JF, Johnson M, Stamler JS, Gaston B. Acute effects of aerosolized S-nitrosoglutathione in cystic fibrosis. Am J Respir Crit Care Med 2002;165:922-6.

25. Griese M, Ramakers J, Krasselt A, Starosta V, van Koningsbruggen $\mathrm{S}$, Fisher $\mathrm{R}$, et al. Improvement of alveolar glutathione and lung function but not oxidative state in cystic fibrosis. Am J Respir Crit Care Med 2004;169:822-8.

26. Hartl D, Starosta V, Maier K, Beck-Speier I, Rebhan C, Becker BF, et al. Inhaled glutathione decreases PGE2 and increases lymphocytes in cystic fibrosis lungs. Free Radic Biol Med 2005;39:463-72.

27. Bishop C, Hudson VM, Hilton SC, Wilde C. A pilot study of the effect of inhaled buffered glutathione on the clinical status of patients with cystic fibrosis. Chest 2005;127:308-17.

28. Gressier B, Lebegue S, Gosset P, Brunet C, Luyckx M, Dine T, et al. Protective role of glutathione on alpha-1-proteinase inhibitor inactivation by the myeloperoxidase system. Hypothetic study for therapeutic strategy in the management of smokers' emphysema. Fundam Clin Pharmacol 1994;8:518-24.

29. Wiedemann HP, Stoller JK. Lung disease due to alpha 1-antitrypsin deficiency. Curr Opin Pulm Med 1996;2:155-60.

30. Rahman I, MacNee W. Lung glutathione and oxidative stress: implications in cigarette smoke-induced airway disease. $\mathrm{Am} \mathrm{J}$ Physiol 1999;277(Lung Cell Mol Physiol. 21);L1067-88.

31. Yang WH, Purchase ECR. Adverse reactions to sulfites. Can Med Assoc $J$ 1985;133:865-7880.

32. Vally H, de Klerk N, Thompson PJ. Alcoholic drinks: important triggers for asthma. J Allergy Clin Immunol 2000;105:462-7.

33. Vally H, Thompson PJ. Role of sulfite additives in wine induced asthma: single dose and cumulative dose studies. Thorax 2001;56:763-9.

34. Giffon E, Vervloet D, Charpin J. Suspicion on sulfites. Rev Mal Respir 1989;6:303-10.

35. Nolan AL. The sulfite controversy. Food Eng 1983;00:84-589-9.

36. Twarog FJ. Metabisulfite sensitivity in asthma. Allergy Proc 1983:4:100-3.

37. Witshi H. Environmental agents altering lung biochemistry. Fed Proc 1977;36:1631-4.

38. Kipen HM, Fiedler N. Environmental factors in medically unexplained symptoms and related syndromes: the evidence and the challenge. Environ Health Perspect 2002;110 (Suppl 4):597-9.

39. Elberling J, Linneberg A, Dirksen A, Johansen JD, Frolund L, Madsen F, et al. Mucosal symptoms elicited by fragrance products in a population-based sample in relation to atopy and bronchial hyper-reactivity. Clin Exp Allergy 2005;35:75-81. 
40. Pall ML. Multiple chemical sensitivity - the end of controversy. $<$ http://molecular.biosciences.wsu.edu/faculty/pall/pall_mcs.htm $>$ 2006.

41. Pall ML. Elevated nitric oxide/peroxynitrite theory of multiple chemical sensitivity: central role of $\mathrm{N}$-methyl-D-aspartate receptors in the sensitivity mechanism. Environ Health Perspect 2003; 111:1461-4.

42. Awasthi YC, Singh SV, Ahmad H, Moller PC. Immunohistochemical evidence for the expression of GST1, GST2, and GST3 gene loci for glutathione S-transferase in human lung. Lung 1987;165:323-32.

43. Anttila S, Hirvonen A, Vainio H, Husgafvel-Pursiainen $K$, Hayes JD, Ketterer B. Immunohistochemical localization of glutathione S-transferase in human lung. Cancer Res 1993;53:5643-8.

44. Cerrahoglu K, Kunter E, Isitmangil T, Oztosun AI, Isitmangil G, Okutan O, et al. Can't lung cancer patients detoxify procarcinogens? Allerg Immunol 2002;34:51-5.

45. Ye Z, Song H, Higgins JPT, Pharoah P, Danesh J. Five glutathione S-transferase gene variants in 23,452 cases of lung cancer and 30,397 controls: meta-analysis of 130 studies. PloS Med 2006;3:e91.

46. Nakayama T, Churh DF, Pryor W. Quantitative analysis of the hydrogen peroxide formed in aqueous cigarette tar extracts. Free Radic Biol Med 1989;7:9-15.
47. Lannan S, Donaldson K, Brown D, MacNee W. Effect of cogarette smoke and its condensates on alveolar epithelial cell injury in vitro. Am J Physiol 1994;266:L92-L100.

48. Iqbal MP. Mechanisms of drug resistance in cancer cells. Pak J Med Sci 2003;19:118-27.

49. Arrick BA, Nathan CF. Glutathione metabolism as a determinant of therapeutic efficacy: a review. Cancer Res 1984;44:4224-32.

50. Meister A. Selective modification of glutathione metabolism. Science 1983;220:472-7.

51. Mattern J, Koomägi R, Volm M. Expression of drug resistance gene products during progression of lung carcinomas. Oncol Rep 2002;9:1181-4.

52. Yang P, Ebbert JO, Sun Z, Weinshilboum RM. Role of the glutathione metabolic pathway in lung cancer treatment and prognosis: a review. J Clin Oncol 2006;24:1761-9.

53. EM-Quant 10013 Sulfite Test. <http://www.galladechem.com catalog/test_strips/sulfite-test-strips-10-400-ppm-em-quant-1-pk-of100.htm> 2007.

54. Wright $\mathrm{J}$, Littleton $\mathrm{K}$. Defects in sulphur metabolism. Int Clin Nut Rev 1989;9:118-9.

Received December 22, 2006; accepted February 13, 2007 


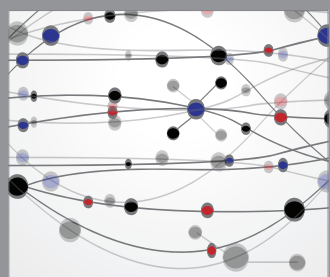

The Scientific World Journal
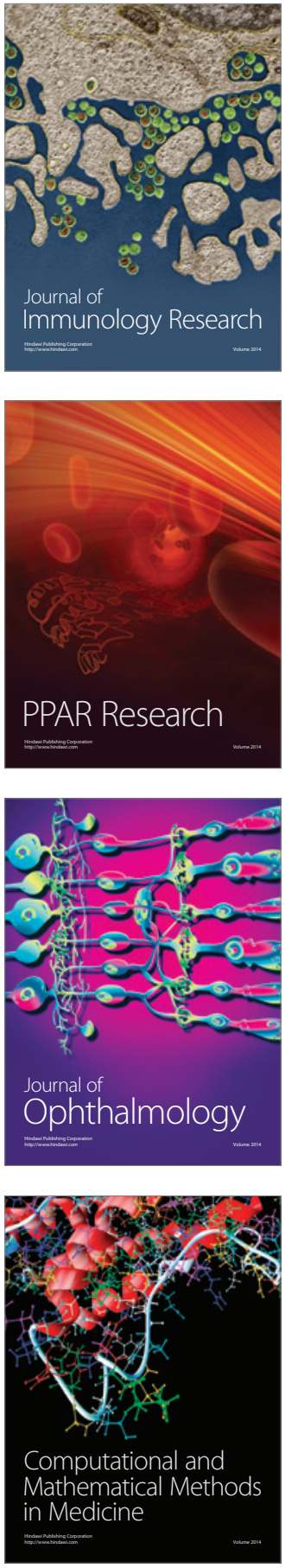

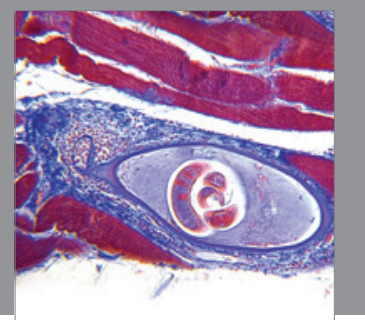

Gastroenterology

Research and Practice
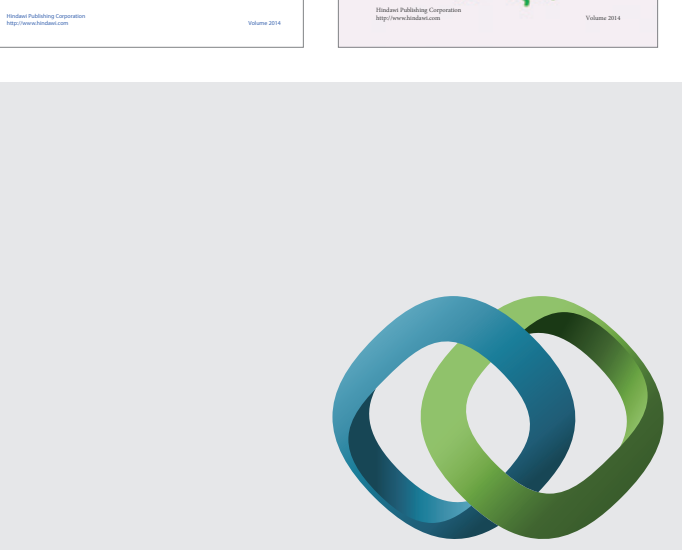

\section{Hindawi}

Submit your manuscripts at

http://www.hindawi.com
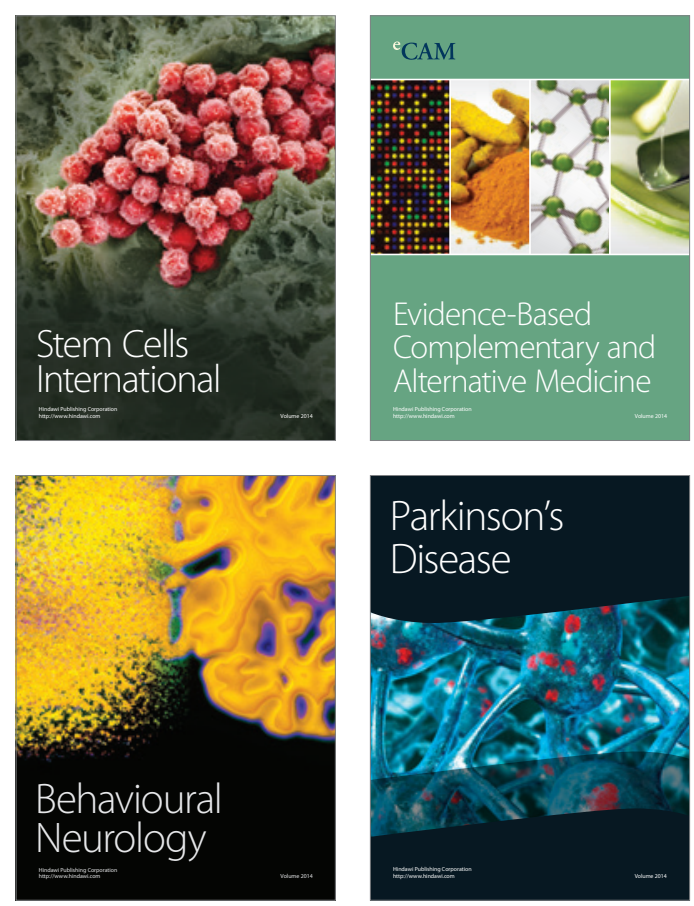

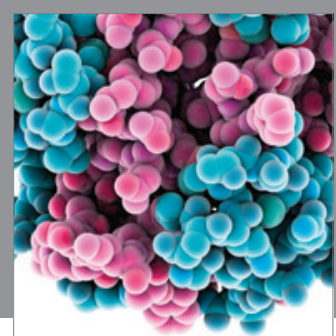

Journal of
Diabetes Research

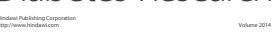

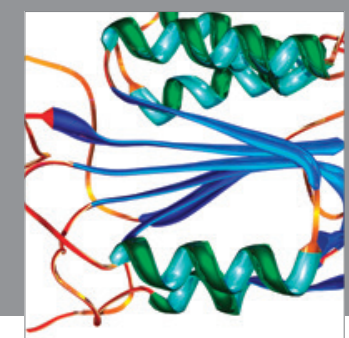

Disease Markers
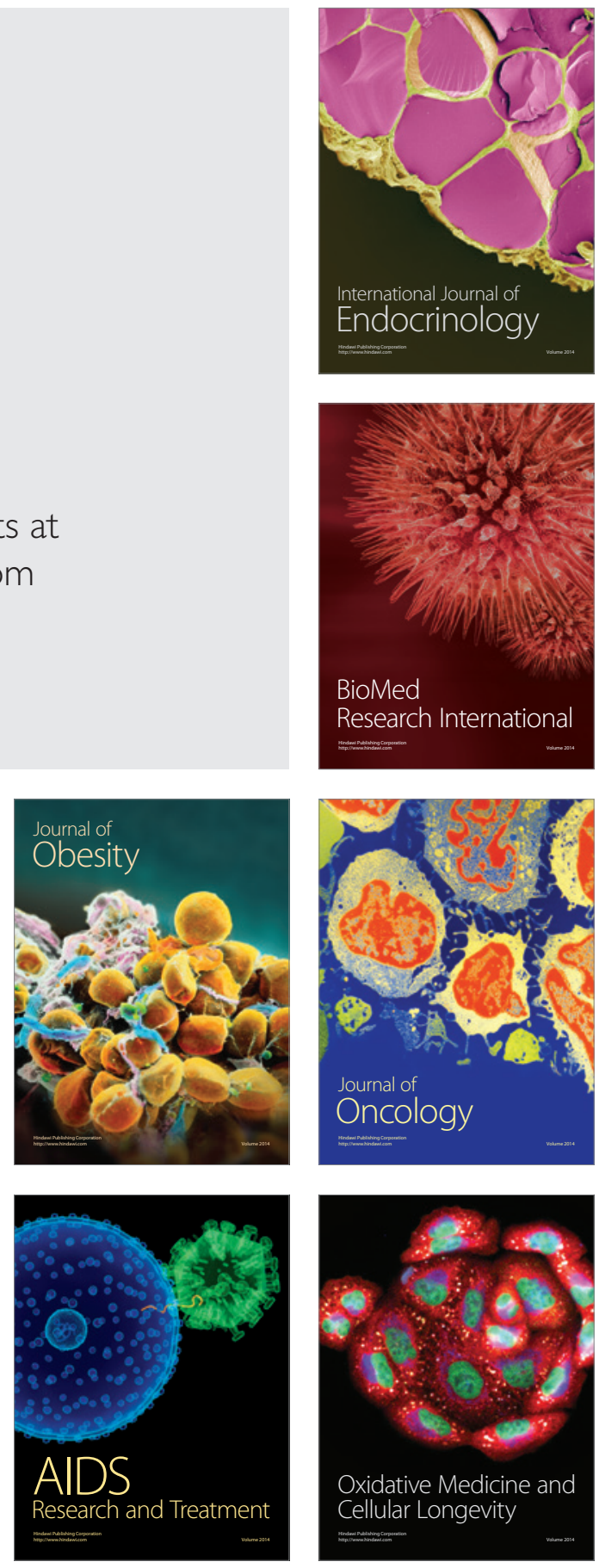